\title{
Exploring the Relationship between Undergraduate Education and Sustainable Transport Attitudes
}

\author{
Junghwa Kim $^{\mathrm{a}}$, Jan-Dirk Schmöcker ${ }^{\mathrm{b}^{*}}$, Satoshi Fujii ${ }^{\mathrm{c}}$

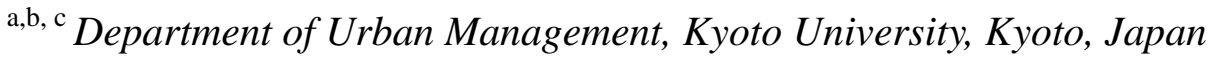 \\ ${ }^{\mathrm{a}}$ kim@trans.kuciv.kyoto-u.co.jp \\ bschmoecker@trans.kuciv.kyoto-u.co.jp \\ 'fujii@trans.kuciv.kyoto-u.co.jp
}

\begin{abstract}
The objective of this study is to discuss the impact of education and environmental attitudes on the support for sustainable transport policies among civil engineering students. We surveyed a total of 524 students from Kyoto University, Japan; asking them about the number of environment related modules they have taken, about their attitudes towards environmental issues as well as their attitudes towards various transport policies. We firstly demonstrate that there is a positive relationship between course selection and environmental concern and discuss self selection issues by comparing civil engineering students with students from other faculties. We then use a Structural Equation Model (SEM) to derive that education and environmental concern also positively influence attitudes to transportation policies aimed at reducing car usage. We conclude that raising awareness of environmental problems and promoting responsibility through the university curriculum is important to educate future transport decision makers as well as to gain general support for sustainable transportation policies.
\end{abstract}

Keywords: University Education; Sustainable Transport, Transport Policy, Environmental Attitudes, Environmental Concern 


\section{INTRODUCTION}

\subsection{Sustainable Transport and University Education}

A large number of professionals involved in transport planning graduate from engineering departments. Academics as well as professionals alike have understood that engineering, and in particular civil engineering, must undergo major changes. Not only do major universities change the name of civil engineering departments but also professional bodies redefine the tasks of civil engineering. In the year 2007, the American Society of Civil Engineers (ASCE) for example published their "Vision for Civil Engineering 2025" as a statement that describes a new role for the profession, "a bright, ambitious goal that would guide civil engineers around the globe to a new level of leadership and professionalism". They describe future civil engineers as "master planners, designers, and constructors; lead stewards of the natural environment; master innovators and integrators; managers of risk; and leaders in shaping public policy."

If this is true for Civil Engineering in general it is in particular true for students focusing on urban and transport planning. Planners have more influence on the relationship between nature, humans and the build environment than those being in charge of managing and maintaining infrastructure. In particular in transport planning the close relationship between changes in the infrastructure, human behavior and environmental impacts has been studied. This journal as well as a large number of contributions in other transport journals is devoted to the topic of "sustainable transport". Impacts of "micro-changes" such as changing speed limits on emissions have been studied as well as increasingly attempts are made to model short- and long term impacts of "macro-changes" such as the road network layout. Further, the inseparable relationship between transport and land-use is well known. This means, especially planning students will need to gain a wider understanding regarding the complexity of our environmental system.

"Understanding" of the issues alone is not enough though. Few graduates of planning courses would probably deny that they are aware of the environmental problems caused by traffic. In order to become "lead stewards of the natural environment" students will need to be convinced of the importance of the issues at stake as well as be able to voice their opinion effectively. Ideally education should prepare future decision makers to take a position for the 
common good in various "dilemma situations". Newhouse (1990) writes "Ultimately, people need to be able to make their own moral decisions about environmental matters. The job of educators is to ensure that everyone has all the tools necessary to make responsible environmental decisions." Similarly, Hyde and Karney (2001) conclude that engineering education should not only consider "understanding" but also whether students "care" for the environment.

\subsection{Literature on Education and Environmental Attitudes}

This firstly leads to the question in how far universities can deliver such an education and, more fundamentally, if education can influence environmental problem perceptions and in the long actually change students' attitudes. This appears to have been not much studied specifically for transport planning education. There is though evidence for the impact of university education in more general on students' attitudes, in particular on the impact of economic education. For example Frank et al (1993) study the difference between students majoring in economics and those from other disciplines. They find not only that economic students are less co-operative but also provide some evidence that the difference to students majoring in other subjects increases with length of education. Also Marwell and James (1981) find differences in the co-operative behavior of economic students, whether this is due to their education is though not clear. Hess-Quimbita et al (1996) report evidence that science education appears to help the development of environmental concern. Using a sample of 18,887 students, they demonstrate that human ethical/social values as well as the number of science modules play important roles in the development of environment concern. Therefore students' academic and social integration appears to indirectly influence the development of environmental-friendly attitudes. Similarly, Smith-Sebasto (1995) reports changes in students' perceived environmental responsibility through education. He noted that students completing an environmental studies course showed significantly higher environmental responsibility.

In summary, there is some limited literature suggesting that "environmental consciousness" could, at least to some degree, be taught. This motivated the study that let to this paper. We would like to understand whether course selection and education can play an important role for students to obtain attitudes that encourage them to promote sustainable transport policies in their later working life. In order to derive some firm conclusions on this, one needs to obtain good panel data that illustrate a change in attitudes for the target group, in 
this case engineering students that take specific classes, versus other students with the same background that do not take these classes. Due to difficulties in obtaining such panel data, we focus this paper on an exploration of cross-sectional data regarding environmental and transport policy attitudes of those who choose courses with a focus on environment versus those who choose to study different subjects. As our subsequent analysis will show we believe this is a first important step to understand what curriculum engineering students that will be involved in transport planning should be taught.

\section{DATA}

\subsection{Environmental Education at Kyoto University}

Our analysis is based on a survey among students at Kyoto University. At this university transport planning education is part of the "School of Global Engineering" at undergraduate level which combines varies Civil Engineering related subjects into the curriculum. We survey undergraduate students from different faculties regarding their environmental attitudes in general and their attitudes towards sustainable transport policies in specific. As a proxy for the amount of environmental education received we consider how many modules with the term "environment" included in the module title the student has taken. Figure 1 shows the number of environmental classes offered among faculties at Kyoto University and departments in the engineering faculty. The faculty of agriculture has the most modules related to environment (31) and the faculty of engineering ranks number two with 15 modules that include the term environment. Within the faculty of engineering, the department of global engineering, which includes transport and urban planning, offers seven "environment modules" and therefore the most compared to other departments (Figure 1). The content of these non-mandatory courses are described in Table 1. In addition to these courses first year students have the chance to take a small group seminar over one semester on a topic of their interest. Several of these so-called "pocket seminars" also focus on environmental issues and we have hence also included these into our count of how many environmental courses a student has taken.

As the classes are non-mandatory the problem of a possible self-selection bias is obvious. We cannot disentangle the effect of interest in environmental issues prior to taking the course from the education effect. What we can still observe though is the change in 
attitudes towards environmental and transport policy issues due to this (combined) effect among students from different grades. Our focus is therefore on undergraduate students, for two main reasons. Firstly, this is a four year course over which the impact of education might be more evident than for the two year Master degree programs. Secondly, for undergraduate students we assume it is reasonable to presume not much prior knowledge and specific interest in transport policy issues. This is likely to be different for Master students who will choose specific transport planning related courses.

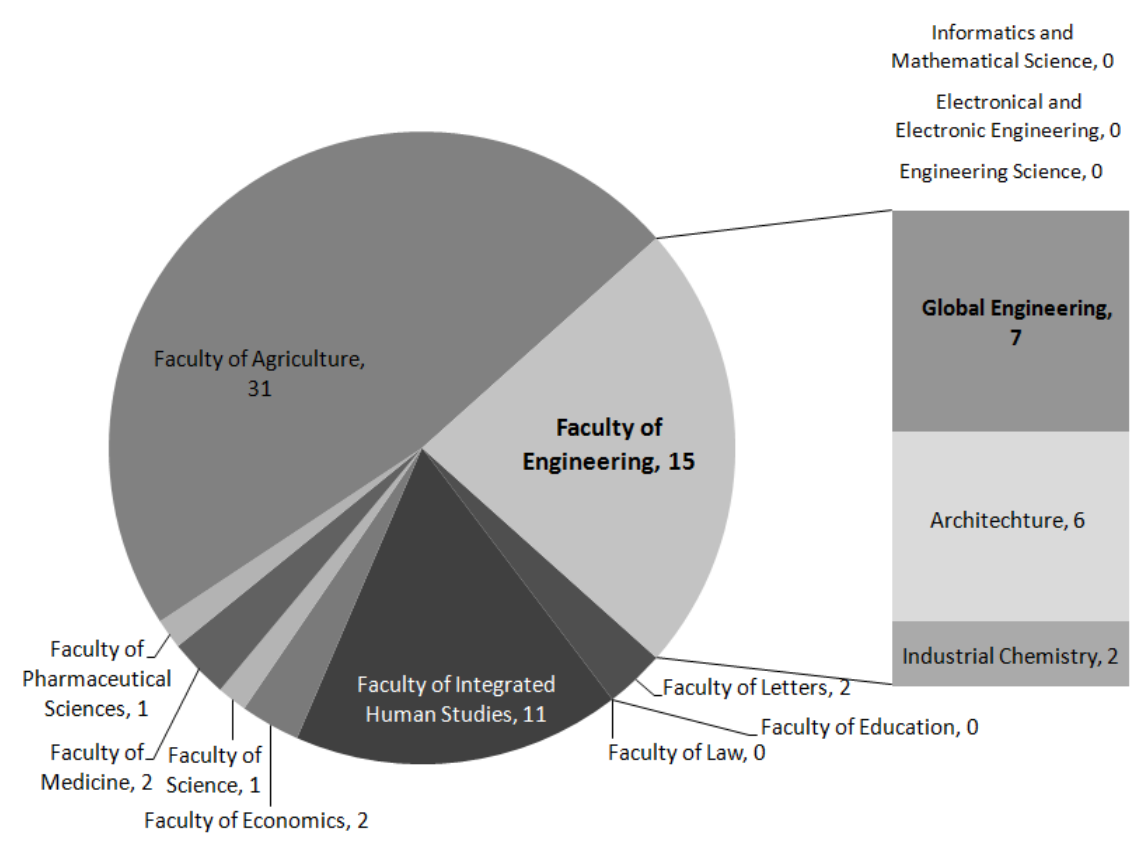

Figure 1. Number of modules with a title including "Environment" in Kyoto University (Faculty of Engineering)

Table 1. Modules with a title including "Environment" in Global engineering (Civil Eng)

\begin{tabular}{|l|l|}
\hline $\begin{array}{c}\text { Name of module } \\
\text { (Grade in which students } \\
\text { take the course })\end{array}$ & \multicolumn{1}{c|}{ Contents } \\
\hline $\begin{array}{l}\text { Atmospheric and Env. } \\
\text { Engineering }\left(3^{\text {rd }}\right)\end{array}$ & $\begin{array}{l}\text { Global warming, ozone layer depletion, and acid rain problems are introduced. } \\
\text { Further air pollution and its health effects are discussed. }\end{array}$ \\
\hline $\begin{array}{l}\text { Basic Environmental } \\
\text { Engineering I }\left(2^{\text {nd }}\right)\end{array}$ & $\begin{array}{l}\text { This class deals with waste water and sewage management. Moreover, the } \\
\text { conservation of the water environment, environmental risk management, and the } \\
\text { promotion of a recycling-based society are introduced. }\end{array}$ \\
\hline $\begin{array}{l}\text { Coastal Environmental } \\
\text { Engineering } \\
\left(3^{\text {rd }}\right)\end{array}$ & $\begin{array}{l}\text { Beach transformation, sediment transport, coastal streams, ocean waves and } \\
\text { irregular waves such as tsunamis are discussed. In addition, the relationship } \\
\text { between coastal ecosystems, engineering ethics and social issues are discussed. }\end{array}$ \\
\hline $\begin{array}{l}\text { Environmental Equipment } \\
\text { Engineering } \\
\left(3^{\text {rd }}\right)\end{array}$ & $\begin{array}{l}\text { The principles of tools that help purifying the environment are described. } \\
\text { Lectures focus on transport material balance, filtration and sedimentation of } \\
\text { particulate matter, waste drying and absorption of gas. }\end{array}$ \\
\hline $\begin{array}{l}\text { Environmental Hygiene } \\
\left(2^{\text {nd }}\right)\end{array}$ & $\begin{array}{l}\text { The lectures introduce the relationship between hygiene and environmental } \\
\text { issues including a discussion on public hygiene. }\end{array}$ \\
\hline
\end{tabular}




\begin{tabular}{|c|c|}
\hline $\begin{array}{l}\text { Geotechnical and } \\
\text { Environmental } \\
\text { Engineering } \\
\left(3^{\text {rd }}\right)\end{array}$ & $\begin{array}{l}\text { In the environmental engineering part of this lecture series, recycling ground } \\
\text { environment and groundwater, soil and groundwater pollution, and waste } \\
\text { disposal are described. }\end{array}$ \\
\hline $\begin{array}{l}\text { Basic Environmental } \\
\text { Engineering II } \\
\left(3^{\text {rd }}\right)\end{array}$ & $\begin{array}{l}\text { Pollution mechanisms of soil and groundwater are taught as well as case studies } \\
\text { of purification technology applications. }\end{array}$ \\
\hline
\end{tabular}

\subsection{Respondents}

Table 2 lists the surveys that have been undertaken from March to July 2012. All surveys have been conducted during the last 15 minutes of lectures. Table 2 presents the corresponding descriptive statistics of the sample. Students from all grades in civil engineering answered our survey, as well $1^{\text {st }}$ grade chemical engineering students and third year students majoring in the economy faculty. A total of 524 observations were gathered for this study. The average age of respondents is 19.9 years and the proportion of males in the sample is $88 \%$, which is fairly representative of the gender split within the engineering school.

We survey also first year chemical engineering students to understand the effect of prior interest in civil engineering issues on attitudes. We chose chemical engineering partly because we could obtain agreement for surveying in these classes and partly because we believe these students can be a valid control group representing other engineering students with less interest in transport and urban issues. We further survey $3^{\text {rd }}$ year economics students because they take a subject "Transport Economy". Therefore we can assume that they will also have some knowledge about transport planning, though from a different viewpoint and we hypothesise that there might be differences in environmental interest between these two groups in line with above literature.

The selection of the lectures in which we surveyed was not influenced by the topic of the module; we rather chose lectures attended by large student numbers in order to catch the majority of students in each grade during a single survey. The surveys were administered to students in paper form at the end of classes after previously obtaining the agreement of the respective lecturers in charge of the class. We explained that this is a survey to understand students' interest in environmental and transport policy issues and that it is purely for research purposes. Students' were not provided any incentives and the surveys were collected upon completion which took on average 10 minutes. 
We ask students about their socio-demographics as well as which modules they have taken so far. Students in their first and second year had so far, on average, taken less than one module directly related to environment issues, which would mostly be the aforementioned "pocket seminars". In contrast students in the $3^{\text {rd }}$ and $4^{\text {th }}$ grades of global engineering took on average 4.4 environmental modules. This is because the majority of the modules are taught in the second semester of the $2^{\text {nd }}$ as well as throughout the $3^{\text {rd }}$ grade (see Table 1). We note that we could not survey $4^{\text {th }}$ year students separately since at Kyoto University there are no dedicated classes for $4^{\text {th }}$ year students. Instead final year students complete some remaining classes together with $3^{\text {rd }}$ year students if they have not yet collected sufficient credits and otherwise focus on their final year project.

Table 2. Descriptive statistic of data

\begin{tabular}{|c|c|c|c|c|c|c|}
\hline & \multicolumn{3}{|c|}{ Global (Civil) engineering } & \multirow{2}{*}{$\begin{array}{c}\begin{array}{c}\text { Chemical } \\
\text { engineering }\end{array} \\
1^{\text {st }} \text { year }\end{array}$} & \multirow{2}{*}{$\begin{array}{c}\text { Economy } \\
3^{\text {rd }}, 4^{\text {th }} \text { year }\end{array}$} & \multirow{2}{*}{ Total } \\
\hline & $1^{\text {st }}$ year & $2^{\text {nd }}$ year & $\begin{array}{c}3^{\text {rd }}, 4^{\text {th }} \\
\text { year }\end{array}$ & & & \\
\hline Sample size & 138 & 137 & 97 & 101 & 51 & 524 \\
\hline $\begin{array}{c}\text { Environmental classes } \\
\text { taken (mean) }\end{array}$ & 0.52 & 0.93 & 4.43 & 0.04 & 0.65 & 1.31 \\
\hline Age (mean) & 18.7 & 19.6 & 20.9 & 18.7 & 21.5 & 19.9 \\
\hline $\begin{array}{c}\text { Gender } \\
(\% \text { of male })\end{array}$ & 90.6 & 93.4 & 87.6 & 90.1 & 78.4 & 88.0 \\
\hline
\end{tabular}

\section{EDUCATION AND ATTITUDES}

\subsection{Environmental Concern}

In the survey we asked questions measuring the environmental concern of students as listed in Table 3. We distinguish problem awareness from ascribed responsibility as well as personal, self and social dimensions of environmental issues. This set up of questions is based on a large set of literature emanating from environmental psychology. Among others Gärling et al. (2008) report that self problem awareness is an important factor when discussing road 
user charging acceptance in Sweden. Self problem awareness relates to the awareness that "my own behavior is part of the problem" as discussed for example by Choocharukuland and Fujii (2007).

Personal problem awareness instead describes whether a person perceives the problem to be significantly related not just to the general public but to him/her personally (Gärling et al., 2008). The questions for awareness were taken from Schmöcker et al. (2012) and Kim et al (2013). Gärling et al. (2003) noted that awareness of consequences must induce an ascribed responsibility to perform the behavior that in turn activates a moral obligation to perform the behavior. In this study therefore two questions were taken from Gärling et al. (2003) to measure personal and social aspects of ascribed responsibility. All questions were asked on a 7 point Likert scale. Ratings were obtained with verbally defined endpoints and midpoints ("Totally disagree" - "Neutral" -"Fully agree").

Table 3. Survey questions regarding environmental concern

\begin{tabular}{l|l}
\hline Self Problem Awareness & $\begin{array}{l}\text { Do you think the } \mathrm{CO}_{2} \text { that you produce in your daily life will contribute } \\
\text { to climate change and this will negatively influence society? }\end{array}$ \\
\hline Personal Problem Awareness & Do you think global warming will serious damage yourself? \\
\hline Personal Ascribed Responsibility & I am not concerned about the environment (-) \\
\hline Social Ascribed Responsibility & Every citizen must take responsibility for the environment \\
\hline
\end{tabular}

\subsection{Comparative Analysis}

We hypothesize that environmental education has a significant impact on general environmental problem awareness and ascribed environmental responsibility. We first compare $1^{\text {st }}$ year engineering students with those majoring in chemical engineering. Our objective is to understand whether there might be some differences due to environmental interests between the two groups. In other words, differences in environmental attitudes might not be due to education but rather due to attitudinal differences obtained before entering university which might have influenced their choice of subject.

We compared the values of environmental concern between the two groups as shown in Table 4. We find no significant differences in problem awareness. However, the results 
show that students who major in civil engineering seem more concerned about the environment as they score higher on personal responsibility. We further compare civil engineering students in upper grades with those majoring in economy. As shown in Table 5, there are large differences in the environmental education received. The results from the comparative analysis indicate that engineering students show higher environmental problem awareness than students with an economy major. This might suggest an education effect but to separate also here the effect of "interest" from "education" or "age" further data collection will be required.

To separate the effect of prior interest from education and age effects, we compare global engineering students in their $2^{\text {nd }}$ and $3^{\text {rd }}$ grades. These two groups differ significantly in the number of environmental classes taken (0.93 vs 4.43 as shown in Table 6) as discussed before. Assuming that the one to two year age difference in itself has no impact on environmental problem awareness, we therefore suggest that the results from this comparison can be considered as impact of education. We note though that we cannot distinguish from this table whether the difference is due to the environmental lectures or the general education received. In line with above results in Table 5, it is indicated that self and personal problem awareness are higher among the more senior students. This suggests that environmental concern can be increased by (environmental) education.

Table 4.Comparsion of $1^{\text {st }}$ year civil and chemical eng. students

\begin{tabular}{|c|c|c|c|}
\hline Determinants & $\begin{array}{c}\text { Civil Eng } \\
1^{\text {st }} \text { students } \\
\text { Mean (Std. Dev.) }\end{array}$ & $\begin{array}{l}\text { Chemical Eng } \\
1 \text { st students } \\
\text { Mean (Std. Dev.) }\end{array}$ & \multirow{2}{*}{ t-test (p-values) } \\
\hline $\begin{array}{c}\text { Environmental Education } \\
\text { (average number of taken classes } \\
\text { related to environment) }\end{array}$ & $0.51(1.41)$ & $0.04(0.20)$ & \\
\hline Self Problem Awareness & $4.75(1.62)$ & $4.69(1.77)$ & $0.27(0.79)$ \\
\hline Personal Problem Awareness & $4.88(1.67)$ & $4.87(1.70)$ & $0.03(0.98)$ \\
\hline Personal Ascribed Responsibility & $5.62(1.32)$ & $5.05(1.62)$ & $3.01 * *(0.003)$ \\
\hline Social Ascribed Responsibility & $5.31(1.37)$ & $5.13(1.36)$ & $1.02(0.31)$ \\
\hline
\end{tabular}

Significance level: $* * * 0.01, * * 0.05, * 0.1$ 
Table 5. Comparison of $3^{\text {rd }}+4^{\text {th }}$ year civil eng. and economy students

\begin{tabular}{|c|c|c|c|}
\hline Determinants & $\begin{array}{l}\text { Civil Eng } \\
3^{\text {rd }}, 4^{\text {th }} \text { students } \\
\text { Mean (Std. Dev.) }\end{array}$ & $\begin{array}{l}\text { Economy } \\
3^{\text {rd }}, 4^{\text {th }} \text { students } \\
\text { Mean (Std. Dev.) }\end{array}$ & t-test (p-values) \\
\hline $\begin{array}{l}\text { Environmental Education } \\
\text { (average number of taken classes } \\
\text { related to environment) }\end{array}$ & $4.43(1.23)$ & $0.65(0.56)$ & \\
\hline Self Problem Awareness & $5.18(1.50)$ & $4.39(1.47)$ & $0.91 * * *(0.003)$ \\
\hline Personal Problem Awareness & $5.03(1.58)$ & $4.49(1.45)$ & $0.87 * *(0.04)$ \\
\hline Personal Ascribed Responsibility & $5.48(1.56)$ & $5.33(1.49)$ & $0.57(0.57)$ \\
\hline Social Ascribed Responsibility & $5.32(1.43)$ & $5.14(1.40)$ & $0.74(0.46)$ \\
\hline
\end{tabular}

Significance level: $* * * 0.01, * * 0.05, * 0.1$

Table 6.Comparison of $2^{\text {nd }}$ and $3^{\text {rd }}+4^{\text {th }}$ year civil eng. students

\begin{tabular}{|c|c|c|c|}
\hline Determinants & $\begin{array}{l}\text { Civil Eng } \\
2^{\text {nd }} \text { year students } \\
\text { Mean (Std. Dev.) }\end{array}$ & $\begin{array}{l}\text { Civil Eng } \\
3 \text { and } 4^{\text {th }} \text { year } \\
\text { students } \\
\text { Mean (Std. Dev.) }\end{array}$ & t-test (p-values) \\
\hline $\begin{array}{c}\text { Education } \\
\text { (average number of classes taken by the } \\
\text { student related to environment) }\end{array}$ & $0.93(0.43)$ & $4.43(1.23)$ & \\
\hline Self Problem Awareness & 4.61(1.52) & $5.18(1.50)$ & $-2.85 * * *(0.01)$ \\
\hline Personal Problem Awareness & $4.63(1.56)$ & $5.03(1.58)$ & $-1.94 *(0.05)$ \\
\hline Personal Ascribed Responsibility & $5.42(1.53)$ & $5.48(1.56)$ & $-0.30(0.77)$ \\
\hline Social Ascribed Responsibility & $5.24(1.48)$ & $5.32(1.43)$ & $-0.41(0.68)$ \\
\hline
\end{tabular}

Significance level: $* * * 0.01, * * 0.05, * 0.1$ 


\section{EDUCATION AND TRANSPORT POLICY}

\subsection{Environmental Concern and Transport Policy}

There is a large body of literature showing that acceptability and acceptance ${ }^{1}$ of transportation policy, depends on people`s environmental concern for climate change or global warming. In particular Schade and Schlag (2000) demonstrated that the acceptability of road pricing is dependent on people`s problem awareness. Similarly, Steg (2003) argues that people who are more aware of the environmental problems caused by car usage are also more likely to perceive needs for policies to solve these and are therefore more likely to accept environmental friendly policies. Eriksson et al. (2006, 2008) consider personal norms such as moral motivation to reduce environmental problems and the relation toward acceptability of travel demand management measures. They discuss that personal norms influence acceptance through willingness to act indirectly, and also show that there is a direct correlation among various types of travel demand measures. Moreover, Nilsson and Kuller (2000) verified that environmental attitudes and knowledge are strongly related to the acceptance of various traffic restrictions for private cars such as road toll, petrol tax and no parking areas.

\subsection{Attitudes to Environmental Friendly Policies}

Above literature shows evidence that environmental concern influences acceptance of transportation policy. We further showed in previous section that education appears to influence environmental concern. Therefore we hypothesize that education is also related to attitudes of environmental and transportation policies, mediated by environmental concern. To demonstrate this, we measured the attitudes towards various policies aimed at restraining car usage.

In total four questions are asked as examples for environmental friendly transport policy (Table 7). The first question is chosen to measure support for the promotion of public transport. In Kyoto, the subway network is limited but there is an extensive bus network that

\footnotetext{
${ }^{1}$ The term 'acceptability' should be used for hypothetical or not yet implemented schemes whereas for implemented schemes the term 'acceptance' is commonly used (see Gärling et al, 2008, Schuitema et al, 2010).
} 
is frequently used by students. For example the main campus of Kyoto University is accessible by several bus lines but not by subway. The second question aims to understand support for parking restrictions and we ask about attitudes towards parking charges in the CBD of Kyoto. There exist several parking houses as well as small capacity parking lots in Central Kyoto which all charge usually around 500 Japanese yen (around 5 US\$) per hour. With the third question we ask students for the support of periodic car inspections to reduce $\mathrm{CO}_{2}$ emissions. In Japan currently there is a regulation that cars older than ten years must undergo an inspection every 2 years. Finally, expressway pricing is included as a typical TDM policy, because all students will be familiar with this as almost all expressways in Japan are tolled.

Since three of these policies can also be promoted for congestion reduction reasons, we include awareness about congestion problems as an additional control variable in our model. To measure congestion problem awareness, following question was asked: "Do you think the congestion level in Kyoto city is serious?" (mean: 5.17, std. dev.: 1.29). In the same way as for the questions for environmental concern, all questions were asked on a 7 point Likert scale. Also here all ratings were obtained with verbally defined endpoints and midpoints ("Totally disagree" - "Neutral" -“Fully agree"). The transport policy questions were only posed to civil engineering students so that the analysis described subsequently is limited to this group $(\mathrm{N}=$ 372).

Table 7. Questions regarding attitudes towards Environmental Transport Policies

\begin{tabular}{c|l|c}
\hline Transport Policy & \multicolumn{1}{|c}{ Question } & $\begin{array}{c}\text { Mean } \\
\text { (Std. Dev.) }\end{array}$ \\
\hline Public Transport & Do you feel that all citizens should use public transport in Kyoto? & $4.67(1.63)$ \\
\hline Parking Charges & $\begin{array}{l}\text { Do you support parking charge systems like a pay garage in the } \\
\text { CBD or near the train station? }\end{array}$ & $5.14(1.63)$ \\
\hline $\begin{array}{c}\text { Eco Inspection } \\
\text { Pricing }\end{array}$ & Do you support the law of eco-inspection of cars once in 2 years? & $5.15(1.48)$ \\
\hline \begin{tabular}{c} 
Expressway \\
\hline
\end{tabular} & Do you support to pay some fees for using highway? & $4.95(1.45)$ \\
\hline
\end{tabular}

\subsection{Model Estimation}

We estimate Structural Equation Models (SEM) to verify the impact of education on transportation policies using the AMOS 21 software. The structural equations are meant to 
represent casual relationships among the variables in the model. The least-squares method is used for model estimation which is a general method for the analysis of SEM with latent exogenous and endogenous variables. The equations of our hypothesized model are described as follows and shown in Figure 2 where endogenous variables are shown as $\boldsymbol{\eta}$ and exogenous variable as $\xi ; \boldsymbol{\beta}$ and $\boldsymbol{\gamma}$ are the estimated coefficients of the endogenous and exogenous variables respectively (Fox, 2006). The model estimation results are reported in Table 8, along with t-values.

Environmental problem awareness and Ascribed responsibility are both constructed by two indicators each. Self awareness and Personal awareness are grouped as Environmental problem awareness with high Cronbach's alpha of 0.75. Ascribed responsibility includes the two indicators Personal and Social responsibility. For this construct the reliability is not as high (Cronbach's alpha $=0.55)$ but we believe it is still acceptable for this model in which we estimate the the weight for $\gamma_{3}$ and $\gamma_{4}$.

On the right are the attitudes to the four transport policies. We only allow for paths from left to right. We hypothesise that environmental education is a more distal factor than environmental problem awareness and estimate a model embedding the hypothesis of a direct path from Environmental problem awareness to Ascribed responsibility as in Gärling et al. (2003). Environmental problem awareness in turn was hypothesised to influence both Ascribed responsibility and Congestion problem awareness which are considered as direct determinants of the policy attitudes.

The estimated model confirms that, as hypothesized, environmental education is indirectly associated with attitudes to transport policies through Environmental problem awareness and Ascribed responsibility. We do not find a significant path from Environmental problem awareness to Congestion problem awareness so that the latter appears to be a separate variable influencing attitudes towards transport policies. The final model only includes paths that are found significant at least at the $10 \%$ level. The overall goodness of fit of the model appears to be acceptable with $\mathrm{GFI}^{2}=0.97$, Adj GFI $=0.95, \mathrm{RMSEA}^{3}=0.05$,

\footnotetext{
${ }^{2}$ GFI (Goodness-of-Fit-Index): GFI varies from 0 to 1 , but theoretically can yield meaningless negative values. By convention, GFI should be approximately 0.90 or more to accept the model. By this criterion, the present model is accepted.

3 RMSEA (Root Mean Square Error of Approximation): There is adequate fit model if RMSEA is less than or
} 
and $\mathrm{CFI}^{4}=0.94$

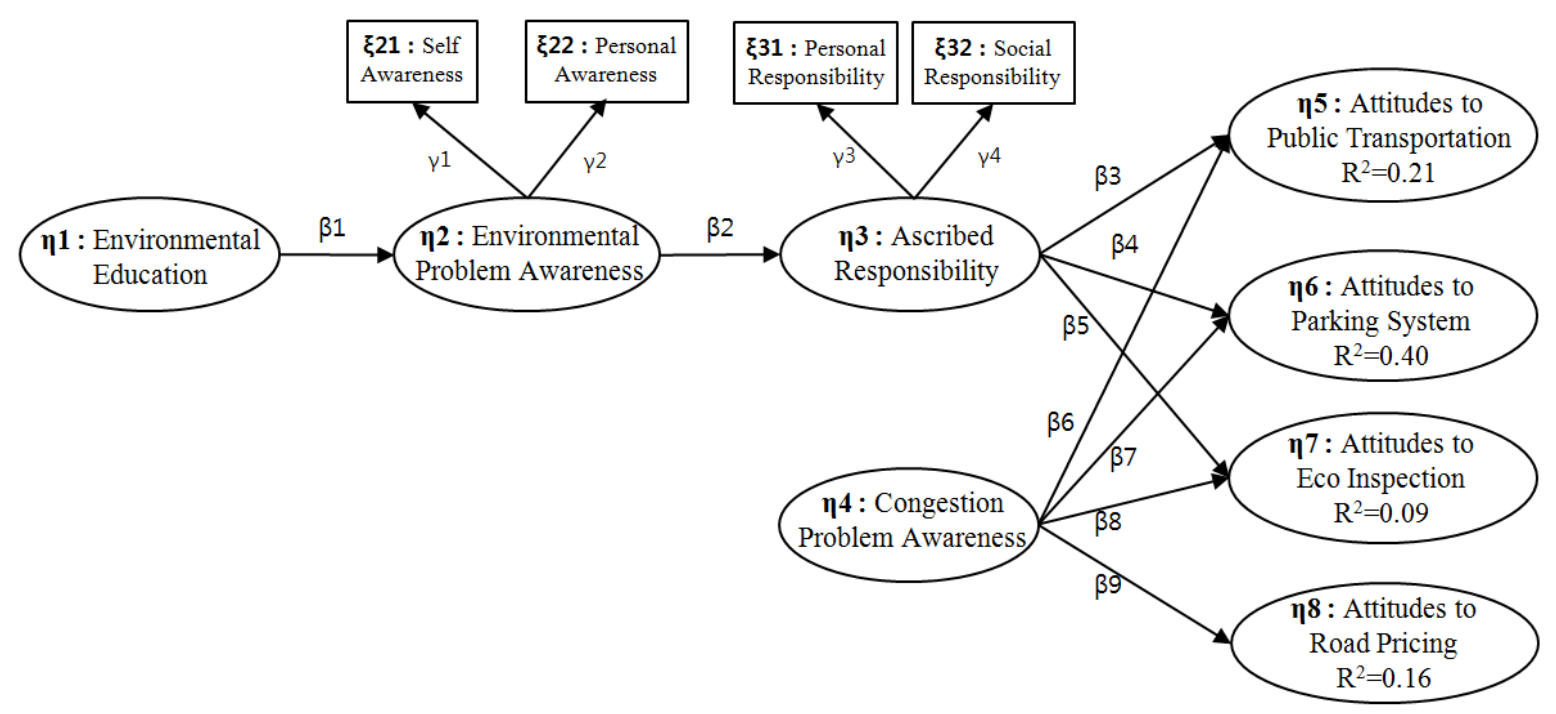

Figure 2. Estimated SEM (Civil Engineering Students Only, N=372)

Considering the path coefficients in Table 8 and total effects in Table 9, following observations appear important to us: Firstly, we find a significant path between education (number of environmental classes attended) and environmental problem awareness. This is equivalent to our results in Section 3 and suggests that (environmental) education influences environmental problem awareness. Moreover, Figure 2 shows that Awareness has a significant effect on ascribed responsibility and responsibility positively influences attitudes towards the transportation policies except for "Expressway Pricing". Finally, we find that congestion problem awareness influences all four policy types. We only hypothesised this link for three of the policies but also found a significant path to eco inspection.

When we compare the effects of ascribed environmental responsibility on policy attitudes, the explanatory power for public transportation support is higher than for the support of eco inspection and parking charges. Furthermore, the $\boldsymbol{\beta}$ coefficients for the latter two policies are only significant at the $10 \%$ level. A significant effect of ascribed

\footnotetext{
equal to 0.08 .

${ }^{4}$ Comparative Fit Index (CFI) : In examining baseline comparisons, the CFI depends in large part on the average size of the correlations in the data. If the average correlation between variables is not high, then the CFI will not be very high. A CFI value of 0.90 or higher is desirable. (Kline, 1998)
} 
responsibility on expressway pricing could not be established. Congestion problem awareness has a strong correlation with the support of parking restrictions. Support for public transport focused policies and road pricing policies are also significantly correlated with congestion problem awareness, but there is a relatively weak correlation with environmental transport policies.

The results are further illustrated by the description of the total effects in Table 9. Education, via problem awareness and ascribed responsibility, primarily increases the support for public transport; the effects on support for eco inspection and parking policy are weaker. These three policies are positively determined by ascribed responsibility as well as congestion problem awareness whereas acceptance of road pricing is influenced by only congestion problem awareness. Both predictors explain $21 \%$ of the variance in support for the public transport policy, $40 \%$ of parking policy acceptance variance but only $9 \%$ of eco inspection acceptance variance. The low value for eco-inspection might be due to many students not having a strong opinion on this issue. As mentioned before, only older cars require currently an inspection and most of the students are not car owners. In how far the results described in this section are influenced further by Kyoto and Japan specific experiences of the respondents should be explored though in further research.

Table 8 . The results of the estimated model

\begin{tabular}{c|l|c|c|c|c}
\hline Link & \multicolumn{1}{|c|}{ Variable } & $\begin{array}{c}\text { Estimated } \\
\text { un-standardized } \\
\text { coefficients }\end{array}$ & S.E & t-value & $\begin{array}{c}\text { Estimated } \\
\text { standardized } \\
\text { coefficients }\end{array}$ \\
\hline$\beta 1$ & $\begin{array}{l}\text { Environmental Education } \rightarrow \text { Environmental Problem } \\
\text { Awareness }\end{array}$ & $5.81^{*}$ & 3.14 & 1.85 & 1.00 \\
\hline$\beta 2$ & $\begin{array}{l}\text { Environmental Problem Awareness } \rightarrow \text { Ascribed } \\
\text { Responsibility }\end{array}$ & $0.61^{* *}$ & 0.07 & 8.64 & 1.00 \\
\hline$\beta 3$ & $\begin{array}{l}\text { Ascribed Responsibility } \rightarrow \text { Attitudes to Public } \\
\text { Transportation }\end{array}$ & $0.35^{* *}$ & 0.13 & 2.77 & 0.36 \\
\hline$\beta 4$ & Ascribed Responsibility $\rightarrow$ Attitudes to Parking System & $0.20^{*}$ & 0.11 & 1.81 & 0.16 \\
\hline$\beta 5$ & Ascribed Responsibility $\rightarrow$ Attitudes to Eco Inspection & $0.21^{*}$ & 0.11 & 1.86 & 0.36 \\
\hline$\beta 6$ & $\begin{array}{l}\text { Congestion Problem Awareness } \rightarrow \text { Attitudes to Public } \\
\text { Transportation }\end{array}$ & $2.04^{* *}$ & 0.71 & 2.85 & 0.93 \\
\hline$\beta 7$ & $\begin{array}{l}\text { Congestion Problem Awareness } \rightarrow \text { Attitudes to Parking } \\
\text { System }\end{array}$ & $2.74^{* *}$ & 0.96 & 2.85 & 0.99 \\
\hline$\beta 8$ & $\begin{array}{l}\text { Congestion Problem Awareness } \rightarrow \text { Attitudes to Eco } \\
\text { Inspection }\end{array}$ & $1.25^{* *}$ & 0.49 & 2.54 & 0.93 \\
\hline & $\begin{array}{l}\text { Congestion Problem Awareness } \rightarrow \text { Attitudes to Road } \\
\text { Pricing }\end{array}$ & $1.69 * *$ & 0.60 & 2.80 & 1.00 \\
\hline
\end{tabular}




\begin{tabular}{c|l|c|c|c|c}
\hline$\gamma 1$ & (Self Problem Awareness) & 1.000 & & - & 0.77 \\
\hline$\gamma 2$ & (Personal Problem Awareness) & $0.97 * *$ & 0.09 & 11.19 & 0.76 \\
\hline \multicolumn{2}{|l|}{ Ascribed Responsibility (Cronbach`s alpha =0.55) } & 1.000 & & - & 0.52 \\
\hline$\gamma 3$ & (Personal Responsibility) & $1.08^{* *}$ & 0.14 & 7.65 & 0.58 \\
\hline$\gamma 4$ & (Social Responsibility) &
\end{tabular}

${ }^{*} p<0.10,{ }^{* *} p<0.05$

Table 9. Total effects on transport policies

\begin{tabular}{c|c|c|c|c}
\hline $\begin{array}{c}\text { Attitudes to } \\
\text { Transport Policy }\end{array}$ & $\begin{array}{c}\text { Congestion } \\
\text { Problem } \\
\text { Awareness } \\
\text { (direct effect) }\end{array}$ & $\begin{array}{c}\text { Education } \\
\text { (indirect effect) }\end{array}$ & $\begin{array}{c}\text { Environmental } \\
\text { Problem } \\
\text { Awareness } \\
\text { (indirect effect) }\end{array}$ & $\begin{array}{c}\text { Ascribed } \\
\text { Responsibility } \\
\text { (direct effect) }\end{array}$ \\
\hline $\begin{array}{c}\text { Attitudes to } \\
\text { Public Transportation }\end{array}$ & $2.04^{* *}$ & $1.25^{* *}$ & $0.22^{* *}$ & $0.35^{* *}$ \\
\hline $\begin{array}{c}\text { Attitudes to } \\
\text { Parking System }\end{array}$ & $2.74^{* *}$ & $0.72^{*}$ & $0.12^{*}$ & $0.20^{*}$ \\
\hline $\begin{array}{c}\text { Attitudes to } \\
\text { Eco Inspection }\end{array}$ & $1.25^{* *}$ & $0.76^{* *}$ & $0.13^{* *}$ & $0.21^{* *}$ \\
\hline $\begin{array}{c}\text { Attitudes to } \\
\text { Road Pricing }\end{array}$ & $1.69^{* *}$ & - & - & - \\
\hline
\end{tabular}

${ }^{*} p<0.10,{ }^{* *} p<0.05$

\section{CONCLUSION}

Sustainable transport is not achievable without planners who fully embrace such policies. Planners are "created" at universities through appropriate education. Many major universities are nowadays rethinking therefore their engineering curriculum to a) address a more global audience and $b$ ) to respond to changing needs towards more sustainable transport policies. Environmental education is in many institutions seen to be of primary importance though evidence on the impact of education has been largely missing so far. The aim of this study is to be a first step to close this knowledge gap.

With a survey among Kyoto University undergraduate students, we show that already first year civil engineering students perceive higher responsibility for environmental problems than students from chemical engineering which we take here as a control group for students with other majors. This suggests that the connectedness of infrastructure and environment is understood already fairly early on. 
We further showed that senior civil engineering students appear to have higher environmental problem awareness than students majoring in economy. Whether this is due to education or prior interest in environmental issues we cannot distinguish though. Independent of distinguishing the cause for the difference, our findings suggest that graduates with an economic major might have a different outlook on transport problems than graduates from engineering faculties. This is in line with Yezer et al. (1996) who compared cooperation in dilemma situations between economic students and those belonging to other faculties. They found that economic students co-operate less and that exposure to economic classes is correlated with lowered cooperation. Erikson (2008) also shows that cooperation in dilemma situations and pro-environmental behavior are related.

We also verified that, among civil engineering students, education increases environmental problem awareness. Problem awareness includes "self and personal aspects", i.e. understanding of the environmental effects of one's own actions as well as the effects of environmental problems on one's own future. Such problem awareness will help transport decision makers to understand the importance of sustainable transport policy. We could not verify any direct education effects on ascribed responsibility which we would also hope for. In particular gaining "social ascribed responsibility" will help transport planners to understand the role of community involvement for achieving sustainable transport. There appears to be though an indirect effect of education on ascribed responsibility via problem awareness.

Our fourth major finding is that education also influences attitudes to transportation policies, again highlighting the role of university education in shaping our future transport policies. We demonstrate with an SEM analysis that congestion awareness and ascribed responsibility influence attitudes towards various transportation policies among engineering students. It is shown that support for transport policies that promote public transport and car use restrictions, are significantly correlated with environmental concern. This means that students who have been better educated about environmental issues are more likely to support the usage of public transport or the need of other environmental policies. More generally, one might also conclude that increasing public awareness of, and responsibility for, environmental issues is important to gain wider support for specific transportation policies.

We believe therefore that our study highlights the role of education for attitudes to 
transport policy. We show the effect of environmental education but cannot clearly distinguish it from the general education effect. Therefore it is beyond this study to give some specific suggestions on detailed subjects that should be included in a curriculum. What we can conclude though is the importance of raising the perception of responsibility and problem awareness through education. Connected to this and our findings by comparing students from different faculties, we suggest that our study implies that employers of graduates are well advised to consider not only knowledge and skills but rather wider education and general environmental interests when recruiting.

Our study clearly has some limitations, as already discussed in various parts of this paper. We conclude this paper by highlighting three main issues that we hope can be addressed in further work with additional data. Firstly, our proxy for the amount of environmental education is the number of modules students have taken with the name "environment" in the module title. Obviously, also other modules might teach environmental aspects and we cannot distinguish further the content or quality of education with our survey. Secondly, as mentioned, in our comparison with students from other faculties, we cannot control whether students entering the faculty of engineering already choose this faculty because of previous environmental interests. Thirdly, we did not consider "knowledge" of environmental issues and transport policy directly. Instead we suppose that problem awareness is activated by knowledge about environmental issues (c.f. Schwartz, 1977). We therefore included environmental problem awareness as an indirect index for knowledge. In subsequent work one might ask some direct questions on knowledge of specific environmental as well as transport policy related questions though. Schade and Schlag (2003) indicate that knowledge is an important variable for acceptance of pricing policies, and moreover education should improve knowledge which in turn may change attitudes.

Therefore in future studies we hope to repeat this survey and collect panel data in order to directly measure the change in environmental attitudes over the four years. We further hope that with more detailed data the effect of some specific modules on environmental attitudes can be analyzed. Finally, it is our hope that similar studies might also be conducted at other universities in order to confirm our findings and derive more detailed practical conclusions on how to best educate future transport planners. 


\section{Acknowledgements}

We would like to thank the various staff who allowed us to survey in their classes. In addition we would like to thank Dr. Giancarlo Flores for various discussion related to literature on the vision for civil engineering.

\section{REFERENCES}

American Society of Civil Engineers (ASCE) (2006) Vision for Civil Engineering in 2025. American Society of Civil Engineers, Virginia, USA. Available online from < http://www.asce.org/uploadedFiles/Vision_2025_-_New/TheVisionforCivilEngineeri ngin2025_ASCE.pdf >.

Choocharukuland, K., Fujii, S. (2007) Psychological Factors Influencing Behavioral Intention of Private Car Use in Future Work Trip. Journal of the Eastern Society for Transportation Studies, 7, 211-222.

Eriksson, L., Garvill, J., Nordlund, A. M. (2006) Acceptability of travel demand management measures: The importance of problem awareness, personal norm, freedom, and fairness. Journal of Environmental Psychology, 26, 15-26.

Eriksson, L., Garvill, J., Nordlund, A. M. (2008) Acceptability of single and combined transport policy measures: The importance of environmental and policy specific beliefs. Transportation Research Part A: Policy and Practice, 42, 1117-1128.

Eriksson, L. (2008) Pro-environmental travel behavior:The importance of attitudinal factors, habits, and transport policy measures, $\mathrm{PhD}$ Thesis, Department of Psychology, Umeå University, Sweden.

Fox, J. (2006) Teacher's corner: structural equation modeling with the SEM package in R. Structural Equation Modeling: A Multidisciplinary Journal 13 (3), 465-486.

Frank, R.H., Gilovich, T. and Regan, D.T. (1993) Does Studying Economics Inhibit Cooperation?. The Journal of Economic Perspectives, 7(2), 159-171.

Gärling, T., Fujii, S., Gärling, A., Jakobsson, C. (2003) Moderating effects of social value orientation on determinants of proenvironmental behavior intention. Journal of Environmental Psychology, 23, 1-9 
Gärling, T., Fujii, S., Gärling, A., Jakobsson, C. (2003) Moderating effects of social value orientation on determinants of proenvironmental behavior intention. Journal of Environmental Psychology, 23, 1-9

Gärling, T., Jakobsson, C., Loukopoulos, P., Fujii, S. (2008) Acceptability of road pricing. Pricing in road transport: Multidisciplinary perspectives. eds E. Verhoef and E. Bliemer and L. Steg and Wee B. Van, Edward Elgar, Cheltenham.

Hayde, R.A. and Karney, B.W. (2001) Environmental Education Research: Implications for Engineering Education. Journal of Engineering Education, 90(2), 267-275.

Hess-Quimbita, G, Pavel, M. (1996) Assessing an Environmental Attitude Development Model: Factors Influencing the Environmental Attitudes of College Students. Paper presented at the Annual Meeting of the American Educational Research Association (New York, NY, April 8-12th, 1996). Available from < http://eric.ed.gov/PDFS/ED394438.pdf>/.

Kline R.B. (1998) Principles and Practice of Structural Equation Modeling. New York, Guilford Press.

Kim, J., Schmöcker, J-D., Fujii, S., Noland, B.R. (2012) Attitudes towards Road Pricing and Environmental Taxation among U.S. and U.K. Students. Transportation Research Part A: Policy and Practice, 48, 50-62.

Marwell, G. and James, R.E. (1981) Economists Free Ride, Does Anyone Else?. Journal of Public Economics, 15, 295-310.

Newhouse, N. (1990) Implications of Attitude and Behavior Research for Environmental Conservation. Journal of Environmental Education, 22 (1), 26-36.

Nilsson, M., Kuller, R. (2000) Travel behaviour and environmental concern. Transportation Research Part D: Environment and Transport, 5, 211-234.

Schmöcker, J-D., Pettersson, P., Fujii, S. (2012) Comparative Analysis of Proximal and Distal Determinants for the Acceptance of Coercive Charging Policies in the U.K. and Japan. International Journal of Sustainable Transportation, 6(3), 156-173.

Schuitema, G. and Steg, L. and Forward, S. (2010). Explaining differences in acceptability before and acceptance after the implementation of a congestion charge in Stockholm. Transportation Research Part A: Policy and Practice, 44, 99-109 
Schade, J., Schlag, B. (2000) Public acceptability of traffic demand management in Europe. Traffic Engineering and Control, 41(8), 314-318.

Schade, J., Schlag, B. (2003). Acceptability of urban transport pricing strategies. Transportation Research Part F: Traffic Psychology and Behaviour, 6 (1), 45-61.

Schwartz, S.H. (1977). Normative Influences on Altruism. In B Leonard (Ed.), Advances in Experimental Social Psychology. Volume 10, pp. 221-279: Academic Press.

Steg, L. (2003) Factors influencing the acceptability and effectiveness of transport pricing. Acceptability of transport pricing strategies. eds Schade, J. and Schlag, B., Elsevier, Oxford.

Smith-Sebasto, N.J.(1995) The Effects of an Environmental Studies Course on Selected Variables Related to Environmentally Responsible Behavior. Journal of Environmental Education, 26(4), 30-34.

Yezer, A. M., Goldfarb, R.S., Poppen, P.J. (1996) Does Studying Economics Discourage Cooperation? Watch What we do, not what we say or How we play. The journal of economic perspectives, 10(1), pp.177-186. 